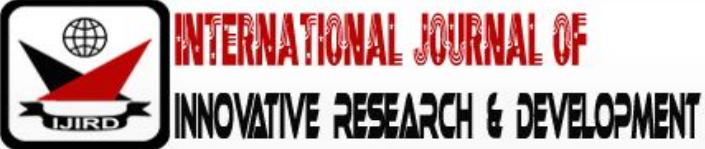

ISSN 2278 - 0211 (Online)

\section{Influence of Stakeholder Participation on the Planning of Water Projects in Kisii County, Kenya}

\author{
Joshua Kimaiga Maragia \\ Project Manager, Department of Quantitative Skills and Entrepreurship Studies \\ Moi University, Kenya \\ Peter Isaboke Omboto \\ Senior Lecturer, Department of Quantitative Skills and Entrepreneurship Studies, \\ Moi University, Kenya \\ Dr. Lydia Maket, \\ Senior Lecturer, Department of Development Studies, Moi University, Kenya
}

\begin{abstract}
:
The study was set to establish whether involving stakeholders in the planning process play a significant role in managing water projects. The objective was to find out whether stakeholder involvement in planning is a contributing factor in successful project management. A mixed methodology was adopted to collect data from the participants in the Nyaribari Chache Sub County, Kenya. The area was purposefully selected because it exhibits common project failures, has a high population growth and, compounds with diverse developmental ventures. Closed-ended questionnaires were used to collect quantitative data, while interview schedules and observation were used to collect qualitative data respectively. A total of 413 questionnaires were distributed to collect data from respondents aged 18 years and above. Further 10 informants were selected and interviewed face to face. Quantitative data were analyzed using Pearson moment correlation while qualitative data was analyzed thematically. The results were presented in tables and figures. The results revealed a higher number of respondents were either involved to a low extent or not at all. The findings show more males and experts dominated in the planning process than females and youths. Further, the findings showed a higher number of water projects were performing below expectations. Involving stakeholders in planning projects is among the key factors for successful project management. The research findings will be an addition to existing knowledge and a reference in effective project's planning and management. And, recommends a rethinking of water project policies to incorporate stakeholders in the planning process.
\end{abstract}

Keywords: Planning, stakeholder's participation, water project management

\section{Introduction}

It is significant to involve stakeholders at all project management phases; however, available literature shows a big number of water projects are performing below expectations'. The scope of this paper was on the planning phase. A high percentage of water project failure rate is ensuing as a critical and a big challenge, further, the world water forum documents that nearly 1.1 billion people have no access to potable and sufficient water supply (World water assessment programms, 2009). In accordance to the existing literature, project's performance, in the rural areas still remain below expectations. To address the issue, governments have shifted to planning projects through stakeholder participation in the planning phase; as a strategy projected to in halving the proportions of people without sufficient and potable drinking water UNDP (2006). The concept is supported by world health organization; that incorporating stakeholders in project planning is a significant management tool.

Stakeholder participation in planning process is imputed among human rights prerequisite for provision of affordable, accessible, safe, and sufficient drinking water to everyone KWAO (2009).

For example, in England water usage stands at 150 litres instead of 1000 litres per capita in accordance to the world health organization recommendations. Hence, there is need for the governments, and other stakeholders; to initiatively value planning through stakeholder participation in raising awareness and encourage behaviour project management change Bressers, M. \& Kuk, S. (2013).

In Thailand, water constitutes a vital and important biological resource considered as a critical component of any human development strategy. Consequently, effective stakeholder involvement in water project planning is increasingly regarded a necessity.

Also, other countries like Nigeria, whence potable and sufficient water is unreliable, the government has developed a sustainable urban water management strategy Bressers, M. \& Kuk, S. (2013). 
More, scarcity of piped water projects has compelled communities find alternative water sources such as wells and boreholes. Inclusively; Malawi faces increasing water scarcity phenomena of serious concern. Environmental information for decision making, 2007; reports an increasing water stress proportion.

Inclusively, people in Africa face water scarcity levels and is projected to worsen as human developmental interventions and populations advance and increase respectively. The importance of sufficient water is advanced by Egyptian literature whence the government imports more than $50 \%$ of her food due to water scarcity. Inclusively, china, India, South Africa and Middle East are affected by water supply and demand capacities Qaddum, H, H. (2008).

The Kenyan government has also embraced a top down to bottom up governance shift in planning and managing water projects despite the shift, water projects are performing below expectations Government of Kenya (2007).

It is not clear whether stakeholders are fully involved in planning projects in Kisii County, thereto, contributing to high project failure rates. To realize the objective, data were collected, analyzed, tabulated and presented in tables and figures.

\subsection{Theoretical Framework}

The study was modeled on Normative Stakeholder theory which was relevant for this study. The premise of the normative stakeholder theory was used to enable the study understand, describe, and explain the influence of involving stakeholders in planning water projects in kisii county. Freeman in 1984, defined a stakeholder as "any individual or group who can either affect or be affected by achievements of the organization's objectives (Freeman, 1984), Inconsistently, Friedman 2006, states "the organization represents grouping of stakeholders whose purpose is to manage stakeholder interests, needs and priorities" (Friedman, 2006). In congruence, Jamali, 2008 states that "incorporation of stakeholders in the planning and decision making and goal setting is a significant factor on projects success" (Friedman, 2006).

Normatively, stakeholder theory spells how incorporating stakeholders in planning projects subscribes to an organization's purpose based on ethical principles (Friedman, 2006).

The concept of stakeholder is applicable in non-governmental organizations, media, business and policymakers and managing water projects (Freeman, 2004). The theory operates as a principle promoter in organization's vision and in maximizing sustainable shareholder value.

The theory unfolds of value as an expression of beliefs, what is worth, quality, goodness, desirability, and subconsciously invoke feelings and further, defines and direct us to goals, frames our attitudes and, provide standards against which behaviour is judged, (Sisa, 2010).

In agreement, Friedman, 2006, on theory evolution; states' stakeholders represent the groups considered vital for the survival and success of the organization (Freeman, 2004).

Therefore, a differentiation of stakeholders is made by considering groups of people with classifiable relationships with the institution (Sisa, 2010). According to Friedman, 2006 stakeholders include: customers, employees, local communities, supplies, distributors and shareholders (Freeman, 2004). Freeman 2004 considers the general public, future generations, past generations, academicians, non-governmental organizations, stakeholder representatives, financiers, government, policy makers and media among others as stakeholders (Freeman, 2004).

The purpose of stakeholder management is to create methods of managing different groups in the planning process and their relationships (UN 2006). The same premise spells out the manager's role in formulating planning strategies projected in satisfying those who have a stake in the cooperation (Freeman 2006).

A major task is how to systematically integrate the relationships and interests of shareholders, employees, customers, suppliers, communities and other groups in the planning process to guarantee successful project management (Friedman, 2006). And, therefore to empower the community.

\subsection{Conceptual Framework}

The study used a conceptual framework as a scheme to represent the relationship between the independent and the dependent variable.

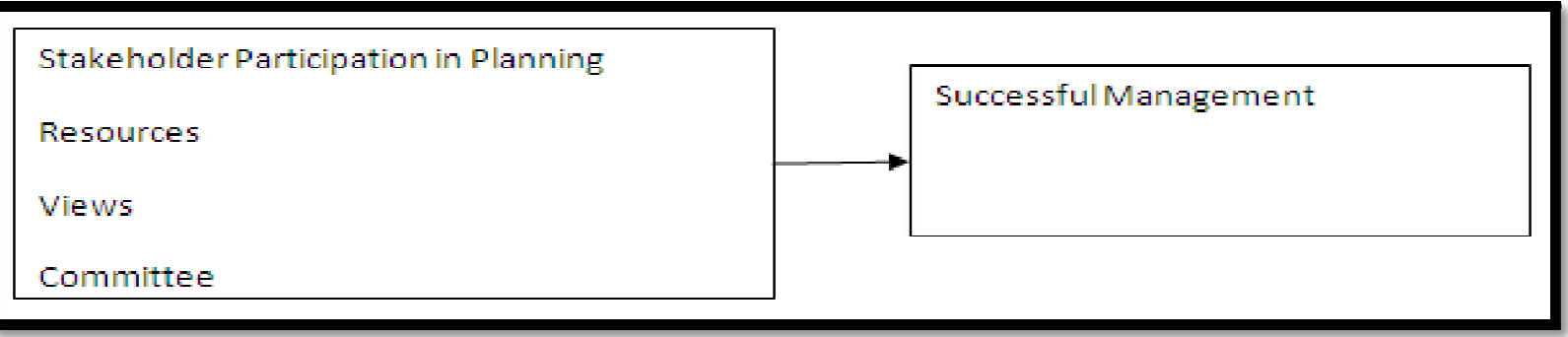

Figure 1

\section{Methodology}

\subsection{Design}

The explanatory sequential design was adopted for this study. A mixed research methodology was respectively used to collect both quantitative and qualitative data. The study was undertaken in Kisii district, Kenya; which comprises 
six wards (keumbu, Ibeno, kisii central, kiogoro, Birongo and Bobaracho). The area was purposefully selected because it exhibits a common water project failure rates, a high population growth, and diverse developmental ventures, which translates to a high-water capacity demand potential. The study targeted 100745 respondents, including both males and females aged 18 years and above. The respondents were considered of mature age and knowledgeable to offer reliable information on planning projects. The sample size was calculated based on accessible population from each representative ward in the Nyaribari Chache Sub County.

\subsection{Participants}

Participants were systematically sampled from a list of relevant stakeholders and from water project's officials. Required sample size of 400 stakeholders was secured through sampling procedures and Taro Yamane formulae. The selected participants were asked to provide information regarding their involvement in planning water projects. The inclusion criterion for participation was those who have lived in at Nyaribari Chache Sub County for at least ten years prior to the study.

\subsection{Data Collection}

In line with sequential explanatory research design, quantitative data was gathered via closed ended questionnaires, while, interview schedule and observation techniques were used to collect qualitative data. The research instruments sought the information pertaining involvement of stakeholders in planning of water projects.

\subsection{Data Analysis}

Collected data was cleaned, coded and analyzed with assistance of SPSS version 20 at a confidence level of $95 \%$ and significance set at $\mathrm{p}<0.05 \%$. Pearson product moment correlation ( $\mathrm{r}$ ) was used to ascertain the strength and direction of the relationship among and between stakeholder participation in planning water projects.

\subsection{Ethical Considerations}

In accordance to Kombo and Tromp 2006, an introductory letter was obtained from Moi University, National Commission for Science, Technology and Innovation (NACOSTI) and the commissioner Kisii County and County Director of Education Kisii County. A number of water projects were visited respondents were interviewed and project photographs taken. Verbal consent was sought from the respondents before questionnaires items were administered and photographs taken.

\section{Results}

The objective of the study was to establish the influence of stakeholder participation in planning and management of water projects in Kisii County, Kenya. Hence, stakeholders were asked to conceptualize, forecast, and mitigate on future uncertainties and risks. The study sampled 413 respondents and asked to complete closed ended questionnaire, while, 10 key informants were interviewed face to face. Thereto, and the study collected both quantitative and qualitative data respectively. The results were tabulated on tables and figures.

\subsection{Questionnaires Response Rate}

Table 1 below shows out of 413 questionnaires which were distributed, 400 were returned. A return rate of 96.8\% percent. The response rates are as illustrated on Table 1 below:

\begin{tabular}{|c|c|c|c|c|}
\hline Respondents & Number Distributed & Returned & Missing & Percentage (\%) \\
\hline Household & 413 & 400 & 13 & $96.8 \%$ \\
\hline
\end{tabular}

Table 1

\subsection{Respondents Educational Level}

To find out whether respondents were knowledgeable enough to participate in planning projects at Kisii County, respondents were asked to indicate their educational levels, and the results tabulated on table 2 below: whence; $0.8 \%$ were on the illiteracy bracket, $18.5 \%$ were primary school-leavers, $10.8 \%$ secondary school-leavers $37.3 \%$ Diploma holders, 8.0 \% undergraduate $19.0 \%$ Master's degree holders and $5.8 \%$ PhD holders.

\begin{tabular}{|c|c|c|c|}
\hline Characteristic & Category & Frequency (n) & Percentage (\%) \\
\hline Level of education & None & 3 & 0.8 \\
\hline & Primary & 74 & 18.5 \\
\hline & Secondary & 43 & 10.8 \\
\hline & Diploma & 149 & 37.3 \\
\hline & undergraduate Degree & 32 & 8.0 \\
\hline & master's degree & 76 & 19.0 \\
\hline & PhDs & 23 & 5.8 \\
\hline & Total & 400 & 100 \\
\hline
\end{tabular}

Table 2: Analysis of Level of Education of the Respondents 
The study results are in line with Lade 2014 whose research on a multi-criteria decision analysis framework for sustainable rainy water harvesting in Ibadan, Nigeria found a correlation between academic differential and managerial skills.

\subsubsection{Stakeholder's Participation at the Planning Phase}

In a bid to establish whether the local community were involved in planning water projects, respondents were asked to complete a questionnaire item and results tabulated on table 3.0 below: The analysis showered $54 \%$ percentage were not involved in planning water projects, while $46 \%$ affirmed to have been involved, 23.2\% (55) got very high consideration in water project site location, also $13.9 \%$ (33) affirmed to a high consideration and ,3.8\% (9) checked on moderate consideration, $27.4 \%(65)$ to a low consideration, however, $25.3 \%$ (60) to a very low consideration. The quantitative findings were in congruence with a qualitative respondents' views:

: "We were not involved in designing and implementing this water project but only saw the government officers from the Ministry constructing the project, then later, youths were involved to provide labour as casuals and on daily payment basis

The findings were consistent with Aschalew (2009) study at Achefer Amhara region which found a high correlation on determinants of household participation in water source planning and management.

When respondents completed a questionnaire item in regard to developing objectives, the results hereunder elicited: $31.2 \%$ (74) indicated a high consideration, $24.9 \%$ (59) to a moderate consideration and $10.5 \%$ (25) a very low consideration. Furthermore, 21.5\% (51) respondents stated their views contributions was very highly considered, $11 \%$ (26) moderately considered, 34.2\% (81) to a low extent and 20.3\% (48) very lowly considered. Finally, 21.1\% (50) of the respondents stated that their contributions in forecasting anticipated risks indicated a very high consideration, $26.6 \%(63)$ highly considered, $14.8 \%$ (35) to a low extent and $18.6 \%$ (44) very lowly considered.

A mean value of 3.09 and standard deviation of 1.158; implied a low stakeholder participation in planning water projects, and thence, probably translated to good number of projects performing below expectations.

The study was consistent with Harvey, \& Reed (2007), whose research findings showered a strong correlation between community member's participation in planning and management of projects in Africa.

The quantitative results were consistent with qualitative data results as in accordance to a respondent who reinterred:

"While some people were invited d to plan for water projects location, set objectives and forecast on anticipated risks, very few people were invited for budgeting and scheduling purposes".

The results were consistent with Adeye and Bello (2013), Grassroots participation in the decision-making process and development programms which showed a correlation between sustainability of community development programs. Nigeria: Ibadan.

Further, at a mean of 2.73 and standard deviation of 1.47 revealed a consistence with Anokye, A. (2013) study on stakeholder participation in water resource management, Ghana, and Birongo and Quyen (2004-2005) analyzing water Governance in Kibera. Nairobi, Kenya.

The study thereto speculated that involving stakeholder's identification, and mitigating risks was projected in project's vision development and in forecasting miscellaneous expenditures among others.

\begin{tabular}{|c|c|c|c|c|c|c|c|c|}
\hline & & $\begin{array}{c}\text { Very Lowly } \\
\text { Considered }\end{array}$ & $\begin{array}{c}\text { Lowly } \\
\text { Considered }\end{array}$ & $\begin{array}{c}\text { Moderately } \\
\text { Considered }\end{array}$ & $\begin{array}{c}\text { Highly } \\
\text { Considered }\end{array}$ & $\begin{array}{c}\text { Very } \\
\text { Highly } \\
\text { Considered }\end{array}$ & Mean & $\begin{array}{c}\text { Std. } \\
\text { Deviation }\end{array}$ \\
\hline Selecting sites & Freq. & 104 & 111 & 15 & 55 & 92 & 2.79 & 1.575 \\
\hline & $\%$ & 26.0 & 27.8 & 3.8 & 13.8 & 23.0 & & \\
\hline $\begin{array}{c}\text { Developing } \\
\text { objectives }\end{array}$ & Freq. & 44 & 76 & 101 & 123 & 33 & 3.07 & 1.159 \\
\hline & $\%$ & 11.0 & 19.0 & 25.3 & 30.8 & 8.3 & & \\
\hline Setting budget & Freq. & 63 & 83 & 82 & 95 & 54 & 2.98 & 1.311 \\
\hline & $\%$ & 15.8 & 20.8 & 20.5 & 23.8 & 13.5 & & \\
\hline $\begin{array}{c}\text { Schedule } \\
\text { activities }\end{array}$ & Freq. & 82 & 138 & 45 & 27 & 85 & 2.72 & 1.462 \\
\hline $\begin{array}{c}\text { Anticipated } \\
\text { risks }\end{array}$ & $\%$ & 20.5 & 34.5 & 11.3 & 6.8 & 21.3 & & \\
\hline & Freq. & 75 & 61 & 50 & 107 & 84 & 3.17 & 1.452 \\
\hline
\end{tabular}

Table 3: Contribution Considered by the Water Projects Planning Committee

\subsubsection{Local Views Consideration at the Planning Phase}

The study sought information pertaining stakeholder participation in planning projects, and analyzed data was tabulated on (Table 4.0 ) below: The respondents were asked whether they were allowed to give opinion on where the project should be stationed and the results revealed that, of the total respondents, $22.3 \%$ (89) strongly agreed that they were allowed to give opinion on where the project should be stationed, $41.5 \%$ (166) agreed, however, $8.5 \%$ (34) disagreed, while $1.3 \%$ (5) strongly disagreed , and $26.0 \%$ (104) were neutral. The mean value was 3.75 and standard deviation 0.939 implied respondents were allowed to give opinion on where the project should be stationed. 
Further, to determine whether the management encouraged each member of the community to give views and ideas on project planning, the study revealed; $14.3 \%$ (57) respondents strongly agreed, $32.5 \%$ (130) agreed, however, $24.5 \%$ (98) disagreed and 19.8\% (79) were neutral. The results summed up to a mean of 3.18 and standard deviation of 1.212. The study hence inferred the management made insufficient efforts towards encouraging each member of the community to give views and ideas on water project planning.

When asked whether only a percentage was allowed to participate in planning water projects, results revealed a mean of 3.55 and standard deviation of 1.160. The tabulated data results were $22.3 \%$ (89) respondents strongly agreed, $34.5 \%$ (138) respondents agreed, while $7.8 \%$ (31) disagreed, and 27.3\% (109) remained uncertain.

In order to find out whether the respondents were given highlight on the benefits and importance of the water projects and how much it will cost, respondents were asked to state the degree to which they concurred with the above statement. The analyzed data revealed, $12.5 \%$ (50) respondents strongly agreed, $25.5 \%$ (102) agreed, while, 22.8\% (91) disagreed, and $15.5 \%$ (62) were neutral. The results summed up to a mean of 2.80 and standard deviation of 1.378 . Thence, the study speculated that studies have not fully established if the respondents were given highlight on the benefits and forecasted cost of the water projects.

Pertaining interaction between the community members involvement in planning and management of projects, the results revealed $22.3 \%$ (89) percent strongly agreed, 10.5\% (42) agreed, while $32.3 \%$ (129) disagreed, 1.8\% (7) strongly disagreed; however, 33.3\% (133) remained neutral. The results summed up to a mean of 3.19 and standard deviation of 1.164 implying that studies have fully established if the interaction between the community members and the management in the planning process is free and fair.

Finally, in a bid to establish if the management is highly concerned with the respondents' views, 27.3\% (109) respondents strongly agreed, 30\% (120) agreed, while, 21.5\% (86) disagreed and 3.8\% (15) stood neutral. The item realized a mean of 3.28 and standard deviation of 1.494 implying a limited concern by the management in reference to respondents' views.

The study was in analogy with Abiona, I.A., \&Bello, W.N. (2013), whose study on grassroots Participation in decision-making process and development programms, research found, correlation between stakeholder participation in planning and developmental programs Sustainability in Nigeria (Abiona,2013).

\begin{tabular}{|c|c|c|c|c|c|c|c|c|}
\hline & & SA & D & N & A & SD & Mean & Std. Deviation \\
\hline $\begin{array}{c}\text { During the planning of the water } \\
\text { project we were allowed to give } \\
\text { opinion on where the project } \\
\text { should be stationed }\end{array}$ & Freq & 5 & 34 & 104 & 166 & 89 & 3.75 & 0.939 \\
\hline $\begin{array}{c}\text { The management encouraged each } \\
\text { member of the community to give } \\
\text { views and ideas on the water } \\
\text { project }\end{array}$ & Freq & 36 & 98 & 79 & 130 & 57 & 3.18 & 1.212 \\
\hline $\begin{array}{c}\text { Only a percentage of the } \\
\text { community was allowed to } \\
\text { participate in planning of the } \\
\text { water project. }\end{array}$ & Freq & 33 & 31 & 109 & 138 & 89 & 3.55 & 1.160 \\
\hline $\begin{array}{c}\text { We were given highlight on the } \\
\text { benefits and importance of the } \\
\text { water projects and how much it } \\
\text { will cost }\end{array}$ & Freq & 95 & 91 & 62 & 102 & 50 & 2.80 & 1.378 \\
\hline & $\%$ & 23.8 & 22.8 & 15.5 & 25.5 & 12.5 & & \\
\hline $\begin{array}{c}\text { The interaction between the } \\
\text { community participation and the } \\
\text { management in the planning } \\
\text { process was free and fair }\end{array}$ & Freq & 7 & 129 & 133 & 42 & 89 & 3.19 & 1.164 \\
\hline & $\%$ & 1.8 & 32.3 & 33.3 & 10.5 & 22.3 & & \\
\hline $\begin{array}{c}\text { Management were highly concern } \\
\text { with our views }\end{array}$ & Freq & 70 & 86 & 15 & 120 & 109 & 3.28 & 1.499 \\
\hline & $\%$ & 17.5 & 21.5 & 3.8 & 30.0 & 27.3 & & \\
\hline
\end{tabular}

Table 4: Participation in Planning the Water Project 


\subsection{A Planning Committee in Managing Water Projects}

The study further, sought to establish who constitutes the planning committee in managing water projects. The results were as shown in (Figure 2) below. From the results, 53.6\% of the respondents noted that more men are involved in managing water projects, $34.6 \%$ more expert, $5.9 \%$ more youths and $5.9 \%$ more women. It was stipulated that underrepresentation of female individuals may impact negatively on project performance since certain gender requirements may not be addressed .

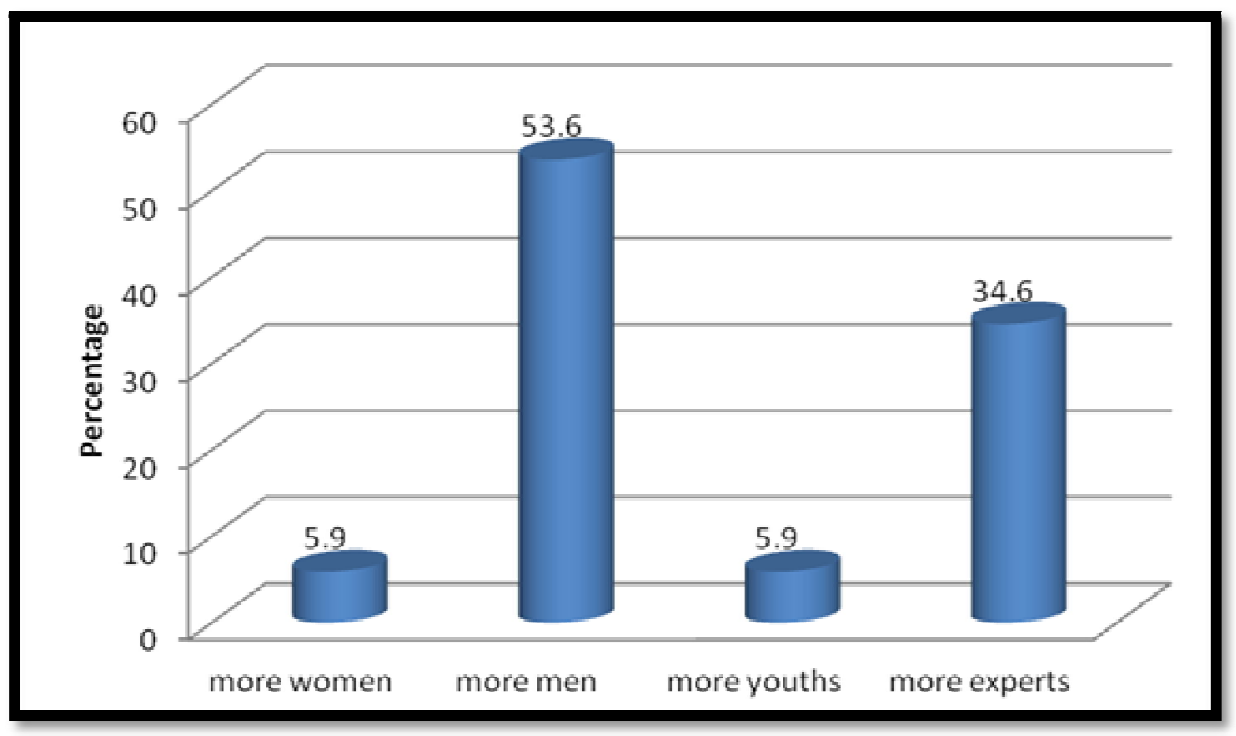

Figure 2: Planning Committee in Managing Water Projects

The study findings were consistent with Pollack (2010) whose study on mainstreaming international governance: The environment, Gender and performance in European Union: Review of international organization 5(3):258-313.found a relationship between gender and planning of community projects. The results concurred with a female respondent views who reiterated that:

"Women are rarely involved in the planning projects and making decisions on the management though they are the main users of water for domestic purposes".

The study speculated that gender gap may impact negatively on planning and management of projects due to nature and nurture differential perspectives.

\section{Conclusion and Recommendations}

The study found a high proportion of 56. \% percent respondents were not involvement in planning water projects. Thus, it was speculated that low stakeholder involvement in the planning process counts among key factors levied on projects performing below expectations. However, since the research was confined to a small area and a short duration and a small sample size, the study recommends a further research on a wider geographical area, a larger sample size, a longer duration, and, a rethinking project on planning policies relevant governments, and probably developed through holistic stakeholder involvement in all project management phases.

\section{References}

i. Aschalew, D. (2009). Determinants of household participation in water source management. Achiever: Amhara Region.

ii. Adeye and Bello (2013). Grassroots participation in decision making process and development programms as correlation of sustainability of community development programmes. Nigeria: Ibadan.

iii. Anokye, A. (2013). Stakeholder participation in water resource management, Ghana Birongo and Quyen (20042005) Analysing water Governance in Kibera. Nairobi: Acts Press.

iv. Bressers, M. \& Kuk, S. (2013). Water governance regimes: Dimensions and dynamics. International journal of water and Governance,1(1-2):133-156.

v. Bressers, M. \& Kuk, S. (2013). Jensen (2009). Understanding the link between water, livelihood and poverty in the Nyando river basin. Kisumu: Macmillan.

vi. CSA (Central Statistical Agency) (2008). Summary and statistical Report of the 2007 population and Housing Census: Population size by Age and Sex. Nairobi: Government printers.

vii. Gebrehiwot, M. (2006). An assessment of challenges of sustainable Rural in Water Supply: The case of Ofla Woreda in Tigray Region, (Unpublished Msc Thesis). A.A.U. Ethiopia: Regional and Local Development Study.

viii. Government of Kenya (2007). Kenya Vision 2030 ministry of state for planning National. Development and Vision 2030. . Nairobi: Government printers.

ix. Harvey, A \& Reed, A (2007). Community managed water supplies in Africa: sustainable or Dispensable?

Community Development Journal, Vol 42 No 3 July 2007 pp. 365-378.

x. Henry, W. (2007). Challenges of water supply in urban Ghana. Sweden: Stockholm. 
xi. Knieper, C. (2010). Analysing complex water governance regimes: the management and transition framework: Environmental scheme policy, 12(7):571-581.

xii. KWAO (2009). Evaluating water and sanitation in Kenya, Human Rights Based Approach in the Kenya water sector for health organization December 2009. New York: McGraw-Hill Irwin.

xiii. Pollack (2010). Mainstreaming international governance: The environment, Gender and performance in European Union: Review of international organization 5(3):258-313.

xiv. Qaddum, H. (2008). Practical Approach to transboundary water benefits sharing, working paper overseas development institutions. London: United Kingdom.

xv. Sisa, K. (2010). An ethnographic study of meanings ascribed by multiple stakeholders to a rural water supply and sanitation project. Nairobi: Option Press and Publishers.

xvi. UNDP, (2006). Human development report 2006, beyond scarcity: power, poverty, and the global water crisis. New York: Island press.

xvii. World water assessment programme (2009). The United Nations World water development report water in a changing world. London: EarthscanA 